\title{
Е.П. Кудрявцева
}

\section{ЗА КУАИСАМИ ВЕНСКОГО КОНГРЕССА}

Аннотация. Статья посвящена некоторым вопросам, которые не были решены на заседаниях Венского конгресса, но имели большой политический резонанс в международной жизни Европь. Прежде всего это касается Восточного вопроса, не получивщего обсуждения в Вене. Статус Ионических островов, защита сербского населения, подвергавщегося истреблению турками, и другие невыполненные условия Бухарестского договора - все это наряду с начавшимся Вторым сербским восстанием требовало внимания европейских политиков, но оказалось за рамками работы Венского конгресса.

Ключевые слова: Венский конгресс, Восточный вопрос, Второе сербское восстание, Бухарестский договор.

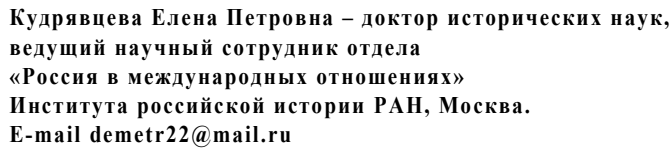

\section{E.P. Kudryavtseva. Behind the Scenes of Vienna's Congress}

Abstract. The article is devoted to a number of problems, that weren't solved during the Congress of Vienna, but had a considerable resonance in the European foreign affairs. First of all this concerns the Eastern Question that wasn't discussed in Vienna. The future of the Ionian Islands, protection of the Serb population, exterminated by Turks and other unfulfilled terms of Bucharest Treaty along with outbreak of the Second Serbian Uprising were under the focus of attention of the European politicians, but left behind during the Congress of Vienna.

Keywords: Congress of Vienna, Eastern Question, Second Serbian Uprising, Treaty of Bucharest.

Kudryavtseva Elena Petrovna - Doctor of Historical Sciences,

leading research fellow of the department «Russia in international

relations» of the Institute of Russian History

of the Russian Academy of Sciences, Moscow.

E-mail demetr22@mail.ru 


\section{РОССИЯ И МИР В ХІХ ВЕКЕ}

Как известно, Восточный вопрос на Венском конгрессе не поднимался. Однако он незримо присутствовал при обсуждении нового послевоенного устройства Европы. Для России важность множественных проблем Балканского региона, Среднего Востока и Черноморского бассейна, составляющих в своем единстве один общий Восточный вопрос, была очевидна: с конца XVIII в. существенно возросла черноморская торговля, связанная с развитием Новороссийского края и черноморских городов. В 1804 г. в Сербии произошло Первое сербское восстание, а с 1806 г. Россия была вынуждена вести затяжную войну с Османской Портой. К этому времени обострилась проблема дальнейшего существования, получившей в 1799 г. Конституцию, Республики Семи соединенных островов, поддержанной российскими представителями. И наконец, своего решения ждал вопрос дальнейшего развития русского военного судоходства через проливы, который как никогда остро встал после прекративших свое действие русско-турецких договоров 1899 и 1805 гг.

Во время проведения Венского конгресса обострились сербско-турецкие отношения, которые регулировались статьями Бухарестского договора 1812 г. Бухарестский мир явился крупной дипломатической победой России. Он значительно укрепил ее положение на южных рубежах: Россия превратилась в придунайскую державу и сохраняла за собой добровольно присоединившиеся к ней области на Кавказе. VIII-я статья договора гласила, что «Блистательная Порта» примет меры для безопасности сербов. Порта дарует им выгоды, которыми уже пользовались подданные Ионических островов, «предоставив им самим управление внутренних дел» $[10$, с. 55]. Известный литератор и реформатор сербского языка Вук Караджич так оценил значение этой статьи русско-турецкого договора: «Турки подписали свободу и права сербского народа в Бухаресте в 1812 г.» [8, с. 317].

Российское правительство, заключив Бухарестский мир с Оттоманской Портой в 1812 г., было вправе требовать от нее выполнения статей договора, в том числе и VIII-й статьи, касающейся Сербии, по которой Турция должна была предоставить ей права самоуправляющейся области в составе Османской империи. Включение этой статьи в текст договора создавало прецедент для выдвижения дальнейших сербских требований и закрепляло за Россией право добиваться безусловного исполнения Портой принятых ею обязательств. Однако Порта затягивала исполнение статей Бухарестского мира, ссылаясь на невыполнение Россией ряда условий - в частности касающихся Кавказского разграничения.

После подавления Первого сербского восстания в 1813 г. по всей Сербии прокатилась волна жестоких расправ над местным населением. Многие жители были вынуждены бежать через Дунай в Австрию, а оттуда в Россию. В этот тяжелый для Сербии момент Россия выступила в ее поддержку. Сербское население искало защиты и покровительства у российского императора, 
обращаясь к нему через российского посланника в Константинополе А.Я. Италинского и дипломатического представителя в Белграде Ф.И. Недобу. Италинский был хорошо информирован о происходящих в Сербии событиях, поскольку поддерживал постоянную связь с сербскими депутатами в турецкой столице и получал отчеты Недобы из Белграда.

Еще до подавления Первого сербского восстания турками его вождь Карагеоргий через своих депутатов просил о материальной помощи и покровительстве [1. Ф. Канцелярия. Оп. 469. Д. 2282. Л. 54-55 об.]. В ответ Италинский пытался защитить сербов, обращаясь к Порте с требованием скорейшего завершения вооруженных действий $[9$, с. 271]. После того как часть сербского населения покинула пределы Сербии, переправившись через Дунай в Землин, сербские старейшины продолжали информировать российские власти о тех беззакониях, которым подвергался сербский народ на своей территории [9, с. 350-351]. Мирные жители безжалостно уничтожались османами, оставлявшими за собой выжженные и опустошенные села. Сербы бросали свои дома, спасаясь в горных ущельях и лесах. Вся страна представляла собой картину безлюдного пепелища.

В октябре 1814 г. в Вену, где в это время проходил конгресс, занятый выработкой нового европейского порядка, прибыл протопоп М. Ненадович, который был представлен двум российским статс-секретарям по иностранным делам К.В. Нессельроде и И. Каподистрии. К декабрю сербы составили обращение к европейским странам с просьбой выступить в их защиту перед Портой. Все державы, кроме России, отказали [4, p. 69]. Только российские представители сочли необходимым подготовить «Меморандум», в котором, обращаясь к османскому правительству, настаивали на прекращении репрессий, указывая, что сербский народ является данником, но не жертвой османов [7, c. 179].

В декабре 1814 г. Нессельроде сообщал Александру I о том, что «вожди несчастной страны... умоляют $\mathrm{B}<$ аше $>$ И<мператорское $>\mathrm{B}<$ еличество $>$ о могущественном вмешательстве перед Оттоманской Портой. Они надеются, что $\mathrm{B}<$ аше $>$ И<мператорское $>\mathrm{B}<$ еличество $>\ldots$ склоните виднейших христианских монархов к совместному демаршу перед турецким правительством» [3, с. 156]. После этого обращения был создан «Проект циркулярной ноты А.К. Разумовского участникам Венского конгресса», датированный не позднее 3 (15) февраля 1815 г. В этом документе содержался призыв не остаться безучастными к бедствиям доведенных до отчаяния сербов и, что особенно важно, подчеркивалась роль России и государя, который призван «ввиду общности религии всегда быть естественным покровителем христиан греко-православного вероисповедания» [3, с. 199]. Следуя предложениям, изложенным в ноте, европейские державы должны провести одновременный демарш перед Портой с требованием прекращения варварских действий, 
ареной которых является Сербия: «Общие основания - суть религия, голос природы и чувство человеколюбия». Таким образом, в данном заявлении можно увидеть первые признаки той идеологической доктрины международных отношений, которая уже осенью 1815 г. была оформлена под названием Священного союза.

Кроме сербско-турецких отношений, которые регулировались Бухарестским договором, в восточной политике России важное место занимал вопрос о судьбе Ионических островов, также ждущий своего решения. И. Каподистрия напоминал российскому императору, что жители островов «хотят быть свободными и независимыми». Он намеревался ставить вопрос о Греческих островах на Венском конгрессе, но европейские державы были не готовы расширять программу своих дискуссий. Свои предложения Каподистрия изложил канцлеру Пруссии Гарденбергу 21 мая (2 июня 1815 г.), формально уже по завершении Венского конгресса. Они заключались в том, чтобы «вернуть Ионическим островам их политическое существование и передать их под покровительство Англии под гарантией других держав - участниц Шомонского договора ${ }^{1} »[3$, с. 369].

Российский император предлагал восстановить государство Семи соединенных островов под покровительством Англии при гарантии трех держав. Решающим при этом был отказ от расчленения республики и передачи части островов Австрии. В русском контрпроекте говорилось: «Ионические острова с прибрежной территорией объявляются свободным и независимым государством под покровительством Великобритании и при гарантии других держав... на основе конституции, существовавшей до 1807 г.» [3, с. 497]. При этом Александр I не отрицал, что «желает утвердить на прочной основе моральное влияние своей империи на Востоке» и надеялся на возобновление действия конституции, разработанной для жителей республики еще Ф.Ф. Ушаковым. Российский император отвергал возможность покровительства Австрии, считая эту идею «абсурдной». Поскольку в Вене этот вопрос не был решен, он получил свое развитие осенью 1815 г., когда острова были переданы под покровительство Англии под названием «Соединенные провинции Ионических островов».

Представители западных держав, не готовые обсуждать на конгрессе вопросы восточной политики, не скрывали, что их целью, прежде всего, является получение от России гарантий целостности Османской империи. Российский император был готов участвовать и в таком соглашении, но Турция не хотела связывать себя никакими договорами с европейскими держа-

1. Шомонский договор об оборонительном и наступательном союзе был заключен в марте 1814 г. между Россией, Великобританией, Австрией и Пруссией в г. Шомон (Франиия). 
вами [6, с. 299]. Этот ее шаг оказался решающим в том, что при последующей работе конгресса Турция более не упоминалась, оказавшись в результате занятой ею позиции вне общей системы договоров, заключенных по завершении Наполеоновских войн.

Второе сербское восстание, вспыхнувшее весной 1815 г., побудило Россию обратить более пристальное внимание на состояние дел в европейской Турции. Если в 1812-1814 гг. российское правительство не могло добиться от Порты исполнения статей Бухарестского мира, то после окончания Наполеоновских войн положение изменилось. Россия заняла лидирующие позиции в международной жизни Европы и была намерена требовать воплощения в жизнь важнейших условий, предоставлявших ей преимущественное влияние на Балканах.

Второе сербское восстание началось, когда еще не был завершен Венский конгресс. Оно существенно отличалось от предыдущего. Новый сербский вождь Милош Обренович не ставил далеко идущих целей полного освобождения Сербии, но предпринял попытку оказать давление на Порту с тем, чтобы добиться от нее уступок по вопросам внутреннего самоуправления. Милош уверял Порту, что борьба направлена не против турецкой власти, а против «несправедливого» белградского паши, притеснявшего сербов. Милош не стремился к решительным победам повстанческой армии, а в дальнейшем добровольно сложил оружие, сочтя более выгодным пойти на перемирие с Портой. Следует признать, что тактика, примененная Милошем Обреновичем в его взаимоотношениях с турецкими властями, способствовала успеху его политики.

Для российских властей начало новых военных действий в Сербии было событием вполне ожидаемым. Недаром российские представители пытались привлечь внимание европейских держав к тому, что происходит в этой провинции Османской империи. После отказа западных союзников выступить перед Портой, Россия осталась единственной защитницей сербского населения. Российский посланник в Константинополе А.Я. Италинский направил османскому правительству ряд официальных нот, в которых выражался протест против военных действий Турецкой армии в Сербии. «Нижеподписавшийся должен... представить Блистательной Порте быстрое умиротворение Сербии как самое надежное средство избежать в будущем нежелательных споров в связи с отступлением от Бухарестского договора в отношении сербов», - говорилось в ноте от 18 (30) сентября 1815 г. [3, с. 530]. Это же требование было повторено в ноте от 29 октября (6 ноября) 1815 г., поскольку вооруженные действия османских войск продолжались [1. Ф. Канцелярия. Оп. 469. Д. 2301. Л. 140 с об.].

Российские власти стремились убедить османское правительство и европейские державы в том, что реальные причины освободительных движений 
на Балканах надо искать в политике репрессий, проводимой Портой по отношению к ее православным подданным. «Причина волнений, постоянно возникающих в связи с актами беспримерной жестокости... кроется в угрожающем поведении и свирепости оттоманских губернаторов и других чиновников», - утверждалось в одной из нот. «Если недоброжелатели и пытались убедить Порту в том, что бедствия, происходящие в Сербии, являются результатом... подстрекательства со стороны России, то нижеподписавшийся не сомневается, что Блистательная Порта отклонила столь оскорбительные внушения», - писал российский посланник. В то же время умиротворение Сербии «есть самое верное средство избежать в дальнейшем неприятных споров в отношении Бухарестского договора» и нежелательного для Порты вмешательства России в ее отношения с сербами [3, с. 460].

Вопрос о Сербии, Дунайских княжествах и Ионических островах был лишь частью общего Восточного вопроса, заключавшегося для России в присутствии и преобладании в регионе Черноморских проливов. Именно эта проблема стала основной не только для Российской империи, но и для других «морских держав» - Англии и Франции - в последующие годы. Греческое восстание 1821 г., Русско-турецкая война 1828-1829 гг., заключение УнкярИскелессийского договора 1833 г., турецко-египетский кризис конца 1830-х годов, Лондонские конвенции 1840 и 1841 гг. и, наконец, Крымская война все это вехи нерешенного Восточного вопроса. Вопроса, который вышел на первый план после Венского урегулирования и который уже зримо просматривался в период Венских заседаний. Россия, будучи жизненно заинтересована в решении оборонительных, экономических и политических задач, связанных с регионом Черноморских проливов, еще в ходе конгресса пыталась привлечь внимание его участников к некоторым из них, но потерпела неудачу. Восточный вопрос, включавший в себя проблему Сербской автономии, был проигнорирован на Венском конгрессе. И сразу же после его завершения вышел на первый план русско-европейских разногласий.

В 1816 г. в Константинополь был направлен новый посланник, Г.А. Строганов, который начал с Портой длительную дискуссию по выполнению статей Бухарестского договора. На этой почве активизировались связи посланника с сербскими делегациями, которые были заинтересованы в русской поддержке и просили российского представителя о помощи в выработке программы сербского освобождения - по существу, сербской конституции. Новый российский посланник отличался самостоятельной и решительной позицией по отношению к османским властям, считая, что от Порты ничего нельзя добиться мирным путем. Строганова поддерживал второй статссекретарь по иностранным делам И. Каподистрия, который придерживался в Восточном вопросе позиции, отличной от официальной $[2$, с. 90$]$. В личной переписке посланник и статс-секретарь позволяли себе критиковать осторож82 
ную политику правительства, строившего свои расчеты на возможности урегулирования спорных русско-турецких вопросов путем переговоров [2, с. 91]. Пользуясь назначением Строганова, Каподистрия пытался обратить внимание российского правительства на необходимость пересмотра условий Бухарестского договора. Он уверял императора в нерезультативности мирных переговоров с Портой, которые являлись главной задачей миссии Строганова, и призывал к выдвижению перед османскими властями новых требований относительно прав Дунайских княжеств и Сербии, для чего следовало, по мнению Каподистрии, прибегнуть к «военной демонстрации на Черном море и на турецкой границе» [5, с. 21-22]. Александр I отверг эти предложения, сославшись на нежелание развязывать новую войну с Турцией, которая в данный момент не могла быть начата ввиду крайне недружественных отношений с Англией и Австрией. Неуступчивость Каподистрии в Восточном вопросе привела к его отставке и смене политического курса в 1822 г.

Несмотря на нежелание российского императора выглядеть покровителем «бунтовщиков», Александр I в то же время не мог полностью отказаться от поддержки единоверцев на Балканах. В инструкции Министерства иностранных дел, полученной Строгановым при отъезде в Константинополь, подчеркивалось неоспоримое право России на покровительство православным подданным Османской империи, закрепленное еще Кучук-Кайнарджийским миром, и намечались задачи, которые должна была решить миссия нового посланника. Речь шла о выработке основ русско-турецких отношений при непременном выполнении Портой целого ряда обязательств, вытекающих из последнего мирного договора и полного урегулирования всех спорных вопросов.

Русско-турецкие переговоры не остались незамеченными в Европе. Российский посол в Лондоне Х.А. Ливен сообщал К.В. Нессельроде, что английский статс-секретарь по иностранным делам лорд Каслри выражал беспокойство по поводу «жесткого тона» последних объяснений Строганова с Портой. Эти объяснения вызвали у недоброжелателей подозрение в завоевательных планах России, противоречивших миролюбивым заверениям императорского кабинета [3, с. 541]. Каподистрия еще до отбытия Строганова в Константинополь предвидел подобное развитие событий. Зная обычный характер ведения переговоров турками, он предупреждал: «Дискуссии... будут такими, что Турция и остальные европейские державы решат, что Россия скрывает свои настоящие планы и не хочет ликвидации притеснения (сербов. - E. K.), а напротив, требует только поводов, по которым бы могла начать новую войну» [12, с. 260].

Строганов отлично понимал, что несговорчивость Порты зависит от поддержки ее Англией и Австрией. Хотя английский посол в Константинополе Р. Листон и австрийский интернунций И. Штюрмер не пользовались полным 


\section{РОССИЯ И МИР В ХІХ ВЕКЕ}

доверием султана, Порта не могла затягивать переговоры с Россией, не заручившись поддержкой западных держав. Так, она запросила посредничества австрийского канцлера К. Меттерниха, усматривая в этом способ решить спорные вопросы в свою пользу [11, с. 290]. Возможность такой поддержки была весьма вероятной. Австрийский интернунций выражал готовность подтвердить процветающее состояние Сербии в случае его привлечения к русско-турецкой дискуссии [12, с. 270].

Задачи урегулирования международных проблем в постнаполеоновскую эпоху, а также создание осенью 1815 г. Священного союза существенно ограничивали возможности России в поддержке освободительных движений на Балканах. Проблемы послевоенного устройства Европы занимали исключительное внимание всех европейских правительств. Связанная узами Священного союза, Россия не могла открыто встать на сторону восставших сербов, а позже - в 1821 г. - поддержать греков. Российская дипломатия избрала другой путь поддержки единоверцев - это было началом длительной политической дискуссии по выполнению Портой условий Бухарестского мира.

\section{Библиография}

1. Архив внешней политики Российской империи (АВПРИ).

2. Арш Г.Л. И. Каподистрия и греческое национально-освободительное движение. 1808 1822. М.: Наука, 1876. 327 c.

3. Внешняя политика России XIX - начала XX века. Документы российского МИД (ВПР). М.: Наука, 1972. Сер. 1. T. VIII. 934 с.

4. Достян И.С. Балканский вопрос в период Венского конгресса. 1814-1815 гг. // Etudes balkanique. 1971. № 1. C. 136-145.

5. Епанчин Н. Очерк похода 1829 г. в европейской Турции. СПб.: Тип. Главного управления уделов, 1905. Ч. 1. $320 \mathrm{c}$.

6. Зак Л.А. Монархи против народов. М.: Международные отношения, 1966. 376 c.

7. Мартенс Ф.Ф. Собрание трактатов и конвенций, заключенных Россией с европейскими державами. СПб.: Тип. М-ва путей сообщения (А. Бенке). 1876. Т. 3. 550 с.

8. Никитин С.А. Вук Караджич и Россия // Очерки по истории южных славян и русскобалканских связей в 50-70-е годы ХІХ в. М.: Наука, 1970. С. 120-136.

9. Первое сербское восстание 1804-1813 гг. и Россия. М.: Наука. 1983. Т. 2. 298 с.

10. Юзефович Т. Договоры России с Востоком, политические и торговые. СПб.: Тип. О.И. Бакста, 1869. 294 с.

11. Гавриловић М. Милош Обреновић. Београд, 1908. Књ. І. 434 с.

12. Jakšić G. Evropa i vaskrs Srbije (1804-1830). Beograd, 1933. 213 p.

\section{References}

Arhiv vneshnej politiki Rossijskoj imperii (AVPRI).

Arsh G.L. I. Kapodistrija i grecheskoe nacional'no-osvoboditel'noe dvizhenie. 1808-1822. Moscow: Nauka, 1876. 327 p.

Dostjan I.S. Balkanskij vopros v period Venskogo kongressa. 1814-1815 gg. // Etudes balkanique. 1971. N 1. P. 136-145.

84 
Epanchin N. Ocherk pohoda 1829 g. v Evropejskoj Turcii. Saint Petersburg: Tip. Glavnogo upravlenija udelov, 1905. Vol. 1. $320 \mathrm{p}$.

Gavrilovih M. Milosh Obrenovih. Beograd, 1908. Књ. I. 434 p.

Jakšić G. Evropa i vaskrs Srbije (1804-1830). Beograd, 1933. 213 p.

Juzefovich T. Dogovory Rossii s Vostokom, politicheskie i torgovye. Saint Petersburg: Tip. O.I. Baksta, 1869. 294 p.

Martens F.F. Sobranie traktatov i konvencij, zakljuchennyh Rossieju s evropejskimi derzhavami. Saint Petersburg: Tip. M-va Putej Soobshhenija (A. Benke). 1876. Vol. 3. 550 p.

Nikitin S.A. Vuk Karadzhich i Rossija // Ocherki po istorii juzhnyh slavjan i russko-balkanskih svjazej v 50-70-e gody XIX v. Moscow: Nauka, 1970. P. 120-136.

Pervoe serbskoe vosstanie 1804-1813 gg. i Rossija. Moscow: Nauka. 1983. Vol. 2. 298 p.

Vneshnjaja politika Rossii XIX - nachala XX veka. Dokumenty rossijskogo MID (VPR). Moscow: Nauka, 1972. Ser. 1. Vol. VIII. 934 p.

Zak L.A. Monarhi protiv narodov. Moscow: Mezhdunarodnye otnoshenija, 1966. 376 c. 